\title{
Undervisning gennem plenumdiskussioner på nettet
}

Annelise Agertoft

Konsulentfirmaet Argo

annelise@argo.dk

http://www.argo.dk

Jørgen Lerche Nielsen

Roskilde Universitetscenter

jln@ruc.dk

http://www.ruc.dk/ jln

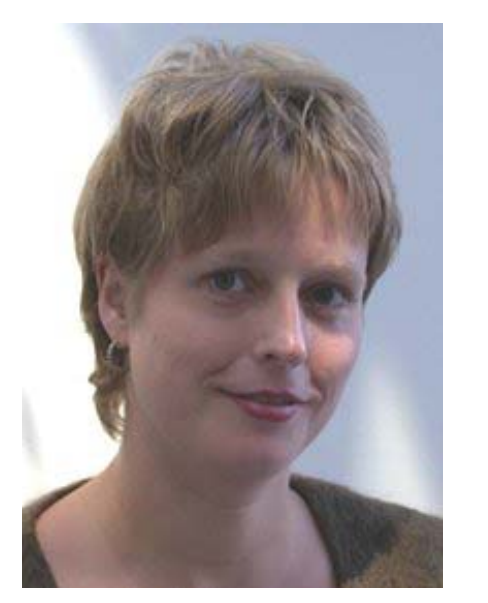

Annelise Agertoft er Cand. Mag., Master i IKT \& Laring. Er specialiseret $i$ design, processtøtte, analyser og evalueringer af kompetenceudvikling på arbejdspladsniveau. Centrale erfaringer og interesser er IKT i uddannelser og kompetenceudviklingsprojekter - scerligt med henblik på netbaseret kollaboration som en central metode i loereprocesserne. Er endvidere bestyrelsesmedlem i Foreningen for Fleksibel Uddannelse i Danmark, www.fluid.dk, og evaluator for EU-kommissionen på Minerva-programmet. Har deltaget $i$ kurset $i$ den nedenfor omtalte case.

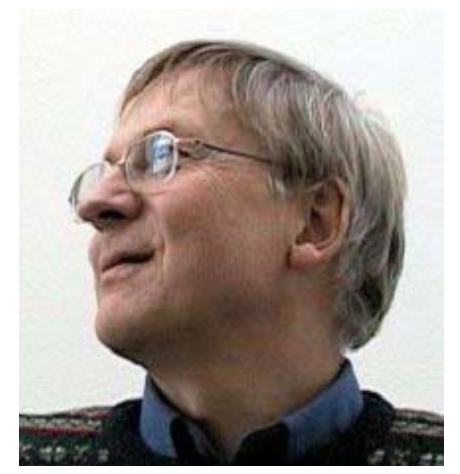

Jørgen Lerche Nielsen er Cand. Mag., lektor i Kommunikation på Roskilde Universitetscenter og underviser på Masteruddannelsen IKT og Laring. 2001-03 med i EU Minerva projektet CLIENT - Collaborative Learning in an International Environment (http://www.clientlearning.org). Sparringspartner for CVU-Sjcellands it-relaterede uddannelsesaktiviteter. Hovedområder er laeringsteorier, laereprocesser og praksisfallesskaber og hvorledes brug af IKT-baserede kommunikationssystemer kan fremme kompetenceopbygning og styrke teamarbejde. 
Undervisning som plenumdiskussioner på nettet behøver ikke at resultere i total virtuel tavshed, men kan udvikle sig til en engageret dialog på et højt fagligt niveau. Med udgangspunkt i et eksempel på 'best practice' beskriver forfatterne, hvordan det via bevidst tilrettelæggelse af forumstruktur, pensum og evalueringskrav kan lykkes at skabe en høj grad af interaktion, der giver deltagerne mulighed for både rum for refleksion og fleksibilitet. Ved at lade deltagerne føre ordet og selv indtage en meget synlig meta-reflekterende rolle kan underviseren lade de studerende bruge hinandens indlæg som 'tænkeredskaber'.

\section{Plenumdiskussioner på nettet}

Undervisning på universitetsniveau kan tilrettelægges som diskussioner i virtuelle konferencefora, hvor de studerende udveksler faglige og metodiske synspunkter og går i dialog med hinanden og underviseren evt. på baggrund af et givet pensum. Vores erfaringer er, at plenumdiskussioner fungerer bedst, når der er eksplicitte mål for og krav til deltagelsen i diskussionerne, når temaerne for diskussionerne er veldefinerede, når der eksisterer en struktur for udfoldelsen af diskussionerne, og når underviseren udviser virtuel tilstedeværelse (dvs. gennem indlæg viser, at han/hun følger med).

I det følgende vil vi beskæftige os med asynkrone, netbaserede plenumdiskussioner i konferencefora. I figur 1 kan man på overskriftsniveau se indlæggene i et konferenceforum i konferencesystemet Virtual-U (http://www.vlei.com). Man kan se, at nogle af indlæggene ligger forskudt, men i forlængelse af hinanden - i "tråde". Ideelt set er hver tråd identisk med diskussionen af ét emne eller én vinkel på emnet. Man kan se, hvem der har afsendt hvilke indlæg og hvornår, om de forsætter en diskussion eller om de tager et nyt emne op. Indlæggene er afsendt asynkront, dvs. forskudt i tid.

\#27 K8 opponent ( by NN on Tue, 09 Oct 2001 (20:30) )

○ \#29 Re:K8 opponent (by XX on Wed, 10 Oct 2001 (11:05))

- $\quad \# 37$ Re:K8 opponent (by NN on Wed, 10 Oct 2001 (21:07))

- $\quad \# 33 \mathrm{k} 9$, moderator på REFLEKSION (by MM on Wed, 10 Oct 2001 (16:30) )

- \#86 Re:k9, moderator på REFLEKSION (by YY on Mon, 15 Oct 2001 (14:14))

- \#94 Re:k9, moderator $=$ diktator ! (by MM on Mon, 15 Oct 2001 (16:43))

- $\quad \# 107$ Re:k9, moderator = diktator ! ( by ZZ on Tue, 16 Oct 2001 (15:49) )

- $\# 146$ Re:k9, moderator $=$ diktator ! ( by YY on Thu, 18 Oct 2001 $(11: 29))$

- \#148 Re:k9, moderator $=$ diktator ! ( by MM on Thu, 18 Oct $2001(14: 56))$

- \#106 Re:k9, moderator på REFLEKSION (by ZZ on Tue, 16 Oct 2001 (15:22))

- \#34 k9, Nivelleret læring/viden (by MM on Wed, 10 Oct 2001 (17:14))

- \#36 K9-Teknikk vs didaktikk-og litt struktur (by VV on Wed, 10 Oct 2001 (19:24) )

○ \#66 Re:K9-Teknikk vs didaktikk-og litt struktur ( by BB on Sun, 14 Oct 2001 (17:03) )

- $\quad \# 38$ k9, virtuel læring vs. face-to-face ( by MM on Wed, 10 Oct 2001 (21:29) )

○ \#39 Re:k9, virtuel læring vs. face-to-face ( by NN on Wed, 10 Oct 2001 (22:03))

Figur 1: Udsnit af dialogen i forummet "refleksion online", MIL 2001, Virtual-U

\section{Casen}

Den case, vi har udvalgt, betragter vi som et eksempel på "best practice" inden for plenumdiskussioner i videregående uddannelser. Vores case er et kursus fra Masteruddannelsen i IKT 
\& Læring (MIL), som er en uddannelse under it-vest i et samarbejde mellem fem videregående uddannelsesinstitutioner, nemlig Aalborg Universitet, Roskilde Universitetscenter, Danmarks Pædagogiske Universitet, Handelshøjskolen i København og Århus Universitet (http://www.hum.auc.dk/mil). MIL-deltagerne kommer primært fra offentlige, men også private virksomheder. Alle deltagere har erfaringer med både anvendelsen af IKT (Informationsog Kommunikationsteknologi) og med tilrettelæggelse af læreprocesser, nogle med mere vægt på det ene end det andet. Rigtig mange er undervisere på uddannelsesinstitutioner, en anden stor del fungerer som uddannelsesplanlæggere eller udviklere af digitale undervisningsmaterialer. Deltagerne kommer fra hele Danmark, men der er også nordmænd blandt deltagerne og enkelte danskere fra andre europæiske lande. Generelt har deltagerne et afslappet og brugerrutineret forhold til anvendelsen af informations- og kommunikationsteknologi.

\section{Opstarten på kurset}

Det kursus, vi koncentrerer os om her, er designet og gennemført af Lektor Elsebeth Korsgaard Sorensen, AAU ( http://www.hum.auc.dk/ansatte/es/index.html). Der var 40 deltagere i kurset. Kurset lå på første modul efter et og parallelt med et andet netbaseret kursus. Kurset var altså et af de første møder for mange af deltagerne med elektroniske konferencefora - i tilfældet MIL er det konferencesystemet Vitual-U. Forud for deltagelsen i kurset havde deltagerne gennemgået et halvdags-brugerkursus i Virtual-U. Udover det havde de mødtes på et tredages face-to-face seminar i Aalborg, hvor der blev introduceret til kurset og dets faglige indhold, og hvor deltagerne havde mulighed for at lære hinanden at kende. Kursets indhold er IKT-baserede kollaborative læreprocesser.

\section{Organiseringen af kurset}

Kursusperioden udspandt sig over perioden 1.-21. oktober 2001. Den første uge var en fordybelses-og forberedelsesperiode, hvor deltagerne individuelt og i grupper læste det til kurset tilknyttede pensum og fordelte en række roller imellem sig med henblik på den følgende periode. Den anden periode var en diskussionsperiode på to uger, hvor deltagerne diskuterede ud fra tre fastsatte temaer.

Hele holdet var af underviseren blevet inddelt i 3 mindre hold, der i hver sit elektroniske konferenceforum diskuterede et tema. Det ene hold diskuterede temaet "kollaboration online", det andet hold temaet "virtuel lærerprofil", det tredje hold diskuterede "refleksion online". Deltagerne var dog blevet opfordret til også at blande sig i diskussionerne i de andre konferencer. På hvert hold var der således 12-15 deltagere, der havde de samme tekster som udgangspunkt for diskussionerne. Men deltagerne blev også opfordret til at inddrage egne erfaringer, andre læste tekster eller andre relevante ressourcer i deres argumentation.

Deltagerne havde på forhånd fået oplyst, at indlæg ikke måtte være på en længde af mere end halv side. For langt de fleste, der har erfaringer med plenumdiskussioner, plejer det slet ikke at være nødvendigt at pålægge deltagerne en sådan restriktion, men i dette tilfælde skulle det vise sig, at være yderst relevant på grund af det høje aktivitetsniveau.

Deltagerne på hvert af de tre hold var inddelt i kursusgrupper à 5-6 personer. Hver gruppe havde en konference til rådighed kun for dem selv, hvori de forud for plenumperioden kunne diskutere pensumteksterne, aftale "taktik" og rollefordeling.

Til kurset var der desuden tilknyttet en meta-konference, hvori samtlige deltagere kunne stille spørgsmål af praktisk karakter og frivilligt deltage i diskussioner med hinanden og med den kursusansvarlige om selve kurset - dvs. dets organisering, didaktisk-pædagogiske tilgang, indhold mv. 
For en række af de studerende bestod en af opgaverne i forløbet $\mathrm{i}$ at opsamle diskussioner i et særskilt indlæg. På opfordring af en af de studerende blev der oprettet et saerligt konferenceforum til disse opsamlinger.

\section{Rollekonfiguration}

Diskussioner i det virtuelle rum plejer at svæve imellem to farer, nemlig på den ene side a) truslen om det "tavse rum", hvor der absolut ingenting foregår, eller hvor det primært er underviseren der er synlig, og b) truslen om "information overload".

For at tage højde for faremomentet ved det tavse rum, valgte underviseren bevidst at lade deltagerne i hver kursusgruppe vælge sig ind på bestemte "roller" i diskussionen. Det vil sige, at hver kursusgruppe iblandt sig skulle vælge en fremscetter, der startede en diskussion (tråd) ved at fremsætte et fagligt synspunkt inddragende noget selvvalgt teori fra pensum. Derudover skulle kursusgruppen vælger en moderator, hvis opgave bl.a. var at skabe sammenhæng mellem indlæg og opfordre "lurkers" til ikke blot at forholde sig iagttagende men aktive i diskussionerne. En deltager måtte påtage sig rollen som opponent, dvs. rollen som den, der modsiger fremsætterens synspunkt. De resterende deltagere i kursusgruppen havde roller som kommentatorer (en rolle fremsætter, moderator og opponent også varetog). Mod slutningen af kursusperioden samlede moderator op på diskussionen. Opsamlingerne fra hver tråd blev lagt ind i opsamlingskonferencen, der således gjorde det muligt for dem, der ikke havde deltaget $\mathrm{i}$ samtlige fora eller tråde at danne sig et overblik over, hvad der var diskuteret hvor. Dermed var der banet vej for yderligere fordybelse i diverse tråde for dem, der måtte have lyst og overskud til at dyrke særlige faglige interesser. (For uddybelse af ideerne bag designet og den benyttede didaktik se Sorensen 2003a: 123; og 2003 b).

\section{Evalueringskriterier for plenumdiskussionerne}

Deltagerne var på forhånd gjort bekendt med evalueringsformen, der indeholdt såvel et sæt af kvantitative som kvalitative kriterier. Bedømmelsen af kurset indgik i en intern bedømmelse af hele modulet, bedømt efter 13-skalaen. Evalueringen gik på den individuelle indsats, men kvalitativt med stor vægt på deltagernes evne til fælles videnopbygning, at lægge op til dialog, at reflektere over andres synspunkter og frembringe nyt af interesse for andre. På denne måde belønnedes altså i høj grad en social tilgang til læreprocessen frem for en monologisk enetalekultur. Kvantitativt krævedes mindst fem indlæg, tre af disse skulle være respons på mindst tre andre studerendes indlæg. Desuden var det et krav, at den enkelte studerendes indlæg udløste mindst tre responser fra andre studerende. Både de kvantitative og de kvalitative kriterier skulle være opfyldt for at bestå.

\section{Kursets struktur}

Kursets struktur fremgår af figur 2. 


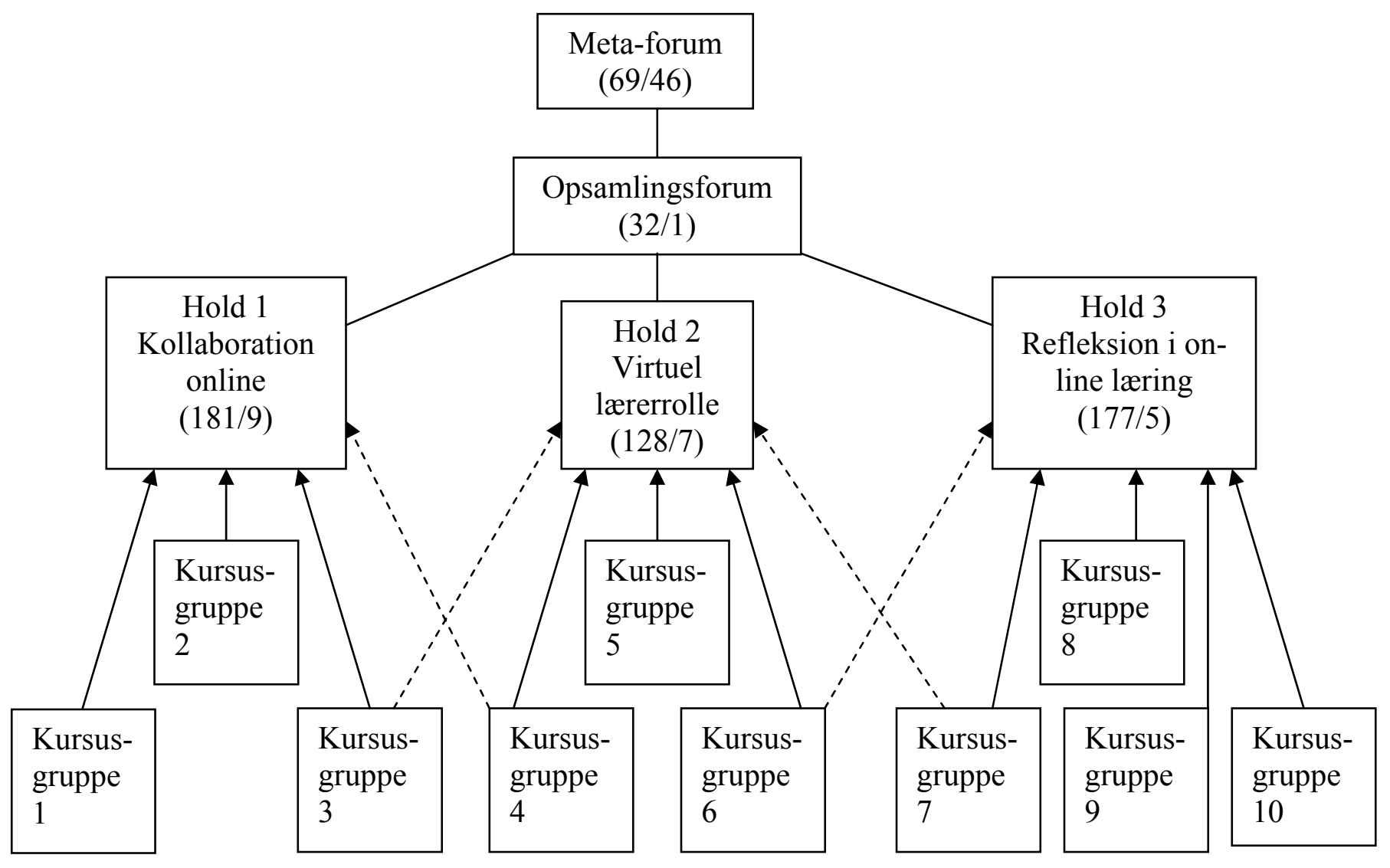

Figur 2: Fora struktur samt antal indloeg. Der er udeladt et antal stiplede pile for overskuelighedens skyld, men hensigten er at illustrere, at de studerende i en vis udstrcekning også kommenterede på diskussionerne i de fora, de ikke var forpligtede på. Tallene i parentes angiver antal studenter/underviser indloeg.

\section{Interaktionen}

Aktivitetsniveauet i de tre fora blev endda meget højt. Normalt klager tilrettelæggere af plenumdiskussioner på nettet over, at de studerende slet ikke er så aktive som ønsket. I dette tilfælde var aktivitetsniveauet så højt, at der opstod det "positive problem", at nogle studerende klagede over "information overload".

Meget få studerende begrænsede sig til det antal indlæg, som var afkrævet i de kvantitative evalueringskriterier. I snit afsendte hver studerende således 12 indlæg set i forhold til de 5, som var minimum. Og de fleste havde også lige været inde at "snuse" i de andre fora og kommentere på en eller flere tråde. En del har muligvis været motiveret af de kvalitative evalueringskrav, som i sig selv kunne betyde, at man måtte afsende flere indlæg, men det er også klart, at en del har været så aktive, simpelthen fordi de blev grebet af stemningen og det gensidige engagement. Dette fremgik også af indholdet af indlæg i meta-konferencen, hvor de studerende parallelt reflekterede forløbet. I denne meta-konference blev der i tilknytning til kurset lagt 69 indlæg af deltagerne. Herudover var der i opsamlingskonferencen 32 deltagerindlæg.

$\mathrm{Nu}$ siger antallet af indlæg naturligvis ikke meget om kvaliteten af indlæggene. En af de bekymringer, man som tilrettelægger af alle plenumdiskussioner vil have er, om de studerende rent faktisk a) holder sig til emnet og ikke divergerer alt for meget og b) at de holder et højt 
nok fagligt niveau, når nu de primært har hinanden som faglige "videnbyggeklodser". I eksemplet med vores case lykkedes det i høj grad de studerende selv at holde diskussionen på sporet, selv om der også var mange indlæg, som ikke holdt sig inden for kursets indhold. Dels var de studerende generelt motiverede for faktisk at diskutere de pågældende tre emner, dels var der uden tvivl også en del, der lod sig motivere af evalueringskravene omkring relevans. Med hensyn til det faglige niveau synes forberedelsesperioden i kursusgrupperne at have sikret en kvalificeret teoretisk referenceramme, ligesom det synes, at en del studerende fra starten skrev indlæg af høj faglig kvalitet og dermed dannede en "standard", som har virket forpligtende. Igen kan evalueringskriterierne sandsynligvis også have spillet en rolle.

Underviseren på forløbet udviste en høj grad af virtuel tilstedevoerelse, det vil sige, at hun var hurtig til at respondere på de studerendes indlæg, når de var rettet til hende, og hun kommenterede også uopfordret på indlæg, som hun følte kaldte på hendes synspunkter. Men det er væsentligt at fremhæve, at underviseren ikke fungerede som "orakel" eller "overdommer", men blot som én af dialogpartnerne i foraene. Netop denne virtuelle adfærd høstede ros i de studerendes indlæg i meta-konferencen og har givetvis medvirket til at skabe både motivation og tryghed ved at forsøge sig. Forskellen $\mathrm{i}$ antal af underviser-indlæg i de tre faglige fora og meta-forum er markant og viser, hvordan underviser bevidst har prioriteret synlighed og tilstedeværelse (46 indlæg i meta-konferencen), men samtidig har ladet de studerendes fælles videnopbygning foregå uden alt for megen indblanding ( 21 indlæg $i$ de tre faglige fora $i$ alt) $i$ en periode på tre uger.

Organiseringen af interaktionen gennem den nævnte rollekonfiguration har vist sig at være et velegnet redskab til at fremme kommunikation og kollaborativ læring i virtuelle diskussionsfora på MIL. Det er dog vigtigt, at rollerne ikke opfattes som for snærende, og at processen ikke udvikler sig til et "tvangsmæssigt Rasmus Modsat scenarie", men at rollerne hjælper deltagerne til at agere i det virtuelle univers uden at de bliver for stramme. For ikke at kvæle deltagernes engagement må der også gives plads for intuitive og kreative dimensioner.

Det er vores vurdering, at den meget bevidste og detaljerede planlægning er hovedårsagen til kursets succes kvantitativt som kvalitativt. Men det skal påpeges, at tilrettelæggerne af denne uddannelse har været "forkælet" i den forstand, at de studerende som udgangspunkt er optagede af læreprocesser. Det vil sige, at de er nemme at "overtale" til at spille med i læreprocesserne. Og at de er næsten lige så optagede af organiseringen af læreprocesserne som af det faglige indhold, hvilket er næsten sammenfaldende i vores case. Dette vil selvfølgelig langtfra være tilfældet på alle universitetsuddannelser. Og det har uden tvivl også haft betydning, at der stort set ingen mentale barrierer har været i forhold til at anvende kommunikationsteknologi.

\section{Læringsteoretisk forståelse}

Den grundlæggende læringsforståelse er konstruktivististisk, social og dialogisk funderet. Herved forstås, at deltagerne skaber deres egen forståelse og gennem en aktiv indsats tilegner sig viden og erkendelse. Man kan sige, at kundskab er noget, som bliver konstrueret og accepteret af en social gruppe snarere end af det enkelte individ. Læreren som tilrettelægger og organisator forsøger at etablere et dynamisk læringsmiljø, hvor viden og mening konstrueres i en udveksling, og ved at man prøver sine argumenter og forståelser af igennem dialog med de øvrige deltagere inden for den sociale kontekst.

Vi vil nedenfor i relation til dialogforudsætninger og -udfoldelser i særlig grad trække på inspiration fra den norske pædagogiske forsker Olga Dysthe (1997,1999, 2003), som på sin side er stærkt inspireret af den russiske litteraturforsker Bakhtin. 


\section{Kommunikation og dialog i virtuelle plenumdiskussioner}

Igennem netbaserede plenumdiskussioner kan der opstå en diskuterende, reflekterende og dialogisk skrivestil, hvor den enkelte deltager fremsætter sine synspunkter og sine argumenter i forhold til en tekst eller et problemområde. Der kan så udvikle sig en "konversation", hvor andre deltagere kommer med deres bidrag og deres synsvinkel på samme tekst. Således kan man sige, at viden opstår ved at de studerende udvikler forståelserne sammen ved at bearbejde teksterne. Ved at de forholder sig refleksivt til teksterne og de fremlagte indlæg, sker det ofte, at den enkelte studerende bliver præsenteret for uventede tilgange til den tekst, som han/hun først har præsenteret. Ifølge Olga Dysthe må deltagerne "indtage en aktiv, svarende holdning til den andens ord, og ny forståelse udspringer af spændingen og kampen mellem de forskellige stemmer" (Dysthe 2003: 322) Denne forståelse bygger på Bakhtins teori om, hvordan betydning bliver skabt gennem dialog og på den estiske semiotiker Lotmans udvidelse af Bakhtin gennem sin teori om teksters 'dobbelte funktion' og tekster brugt som 'tænkeredskaber'. Når vi taler om denne dobbeltfunktion, gælder det både for den, der producerer teksten, og for alle de øvrige deltagere i konferencen - qua modtagere. I og med at meddelelsen fremsættes skriftligt, kan tekstproducenten på en gang præsentere en argumenterende pointe og samtidig være involveret i en kognitiv orienteret tænkeproces. Dette sker også ved, at den studerende så at sige må gå på opdagelser i anden litteratur for herigennem at kunne formidle sit synspunkt bedst muligt.

Andetsteds skriver Dysthe med reference til Bakhtin at "polyfoni eller flerstemmighed betegner ikke kun sameksistensen af mange stemmer, men også dialogisk interaktion mellem dem" (Dysthe 1997: 71). I vores case så vi mange eksempler på, hvorledes der opstod "flerstemmighed" igennem deltagernes fælles refleksion over en tekst, igennem de forskellige eksemplifikationer, som fremkom med baggrund i deltagernes forskellige læsning og varierede praksisbaggrund.

I modsætning til en opfattelse, der udgår fra autoriserede sandheder, så vi i disse diskussionsfora, at deltagerne havde givet sig i kast med en "autentisk opgave", hvilket vil sige, at der ikke findes oplagte rigtige og forkerte svar, og at man i fællesskab har givet sig i kast med en "kompleks opgave", som indbyder til, at de studerende reflekterer, inden de svarer. I anden sammenhæng har Dysthe karakteriseret et sådan processuelt forløb som opsummerende, udfordrende, kontinuerlig fremlæggelse af ny information, hvorved kundskab i læringssammenhæng kan konsolideres.

De mange perspektiver modvirker en forenklet anskuelse af komplekse forhold og skaber et frugtbart potentiale for de studerendes forståelse af de behandlede læringssammenhænge. For eksempel bestod en tråd i vores tilfælde af 6 bidrag, mens en anden tråd indeholdt hele 13 indlæg. Gennem sådanne grundige trådede diskussioner skabes i fællesskab en nuanceret forståelse af de omhandlede temaer. Strækker konferencen sig over relativ kort tid, og indeholder den et væld af forskellige tråde - temaer - kan det dog forekomme svært overskueligt, og nogle deltagere kan nærmest blive lammet af informations-overload. Igennem den virtuelle dialog får en deltager mulighed for at dele sine egne forståelser og synspunkter med de andre, samtidig med at man "lytter" til andres meninger og prøver at forstå dem. Dialogen bliver således en "skriftlig samtale", hvor man organiserer og reorganiserer ens egen opfattelse af verden og dermed ens viden. Igennem en sådan kommunikation og via interaktionen med andre i det sociale fællesskab gives gode forudsætninger for læreprocesser og som led heri konstrueres mening på ny. 
Gennem dialog og diskussion "risikerer" deltagerne at blive "forstyrret" i deres vante tankemønstre - de får mulighed for at undre sig og at stille spørgsmål til såvel egne som andres opfattelser. Vores opfattelse er, at man i en skriftlig dialog lærer mest, når man involverer sig i drøftelser med personer, der er lidt forskellige fra en selv! Eksistensen af sådanne forskelligheder skal derfor generelt ikke ses som en hindring, der skal overvindes, sådan som man umiddelbart ville forledes til at tro. Snarere tværtimod. Netop det, at deltagerne er forskellige, fx med hensyn til tidligere erfaringer, hverdags- og arbejdssituation og uddannelse, har i MIL sammenhæng vist sig at udgøre en særdeles inspirerende og betydningsfuld ressource, som netop har kunnet kvalificere den fælles vidensopbygning

\section{Fordele og ulemper ved asynkrone plenumdiskussioner}

En af fordelene ved den asynkrone dialog i konferencefora er den tidsmæssige fleksibilitet. Derfor ser vi andre arbejdsrytmer end ved face-to-face forløb. Deltagerne kan selv bestemme, hvornår de har de bedste forudsætninger for at sætte sig ved computeren. "Hvornår har jeg tid $i$ forhold til mine omgivelser - familie- og arbejdsforpligtelser? Hvornår har jeg fået en kvalificeret baggrund for at besvare de indlæg, som virkelig har "fået mig op på dupperne"? Når jeg har haft fat i den relevante artikel, som har udstyret mig med argumenter, føler jeg, at jeg har noget nyt at bidrage med. På et sådant tidspunkt kan man være opfyldt af følelsen: "Nu er jeg endelig motiveret for at gå i gang." Netop her adskiller virtuelle asynkrone aktiviteter sig fundamentalt fra stedbunden undervisning - seminar on-campus.

Det samme gør sig gældende sammenlignet med aftalte fysiske møder i en gruppe. Alle skal her i sagens natur være til stede samme sted og inden for samme tidsrum. Alle skal "on time" have gjort deres hjemmearbejde og tillige være i et godt kommunikativt "mood". I virtuel sammenhæng er det modsat muligt efter at have modtaget indlæg fra andre gruppemedlemmer at holde en pause for at give sig tid til at tænke sig om. Og man kan som nævnt via litteratur eller via nettet indhente relevant form for information til støtte for ens svar.

Det er dog værd at være opmærksom på, at det kan være så som så med det asynkrone, hvis de studerende har et meget højt aktivitetsniveau og hvis perioden for det pågældende kursus er af relativt kort varighed. Idet interaktionen i høj grad er baseret på udsagn/respons spørgsmål/svar kan det for enkelte studerende pludselig være for sent at afsende det indlæg, han/hun har formuleret, simpelthen fordi det samme allerede er sagt af andre.

Fordelene ved en del konferencesystemer og i særdeleshed Virtual-U er, at de giver mulighed for at brugeren kan sortere indlæggene i forskellige visninger. Det vil sige, at man modsat face-to-face situationen kan vælge kun at se (og udskrive) indlæg fra bestemte afsendere, indlæg fra bestemte perioder, indlæg med bestemte temaer eller fx kun ulæste indlæg. Det vil sige, at man kan strukturere informationerne så de i høj grad passer til ens behov, modsat face-to-face, hvor man hvad enten man nu ønsker det eller ej, må lægge øre og tid til alle indlæg, medmindre man da helt vælger at blive væk.

Ved at stille krav om et minimum antal indlæg pr. studerende motiveres de studerende til at arbejde med pensum og til at forholde sig reflekterende til de andres indlæg. I face-to-face plenumsituationer er det typisk udmærket muligt at forholde sig mentalt og sprogligt passiv til alle diskussioner, fordi vi af bl.a. praktiske årsager ikke har de samme krav om interaktion og evalueringskriterier der.

I forhold til plenumdiskussioner i det fysiske undervisningslokale gør selve muligheden for at opdele og strukturere en diskussion i forskellige elektroniske fora og tråde det muligt for den enkelte (studerende som underviser) at foretage en tilsvarende mental strukturering. Naturlig- 
vis kan ikke alle diskussioner i realiteten inddeles i afgrænsede kategorier, men selve øvelsen der består i "tvangen" til at forholde sig til, hvordan det man selv vil bidrage med, relaterer sig til det, andre har sagt (det ene eller det andet forum, den ene eller den anden tråd), før man afsender sit eget indlæg, er gavnlig for den kritiske tænkning og logiske argumentation.

I forhold til evaluering på baggrund af plenumdiskussioner ligger der en stor opgave for evaluator, når de kvalitative aspekter vægtes. Her kan man ikke blot måle på noget kvantificerbart, som fx hvis man modsat havde valgt opgaver med multiple choice, som ville kunne bedømmes elektronisk. Med andre ord, hvis man har været god til at tilrettelægge en virtuel dialog, får man både fornøjelsen af et højt aktivitetsniveau og et arbejde med at evaluere de mange indlæg.

Set fra et tilrettelæggersynspunkt er brugen af meta-konferencer særdeles interessant, fordi der her foregår en løbende evaluering af det didaktisk-pædagogiske design samt kursets faglige indhold. I et fremadrettet perspektiv udgør meta-konferencerne derfor et godt redskab for en løbende udvikling af ethvert kursus.

I skriftbaserede diskussioner mangler der vigtige audio-visuelle markører. Risikoen for misforståelser og måske endda uoverensstemmelser er større på grund af denne mangel. Man kan søge at kompensere for denne mangel, blandt andet dels i planlægningen af face-to-face møder, der skaber tryghed, dels ved personlige præsentationssider, dels ved brug af forskellige symboler, der markerer sindsstemning, tonefald mv. (Agertoft m.fl. 2003a og b). Modsat den dialog, der foregår face-to face, er det muligt for deltagerne i det virtuelle rum at ignorere et indlæg. Denne mulighed er der sjældent face-to-face, hvor samtidighed og høflighed fordrer et svar. Tavsheden i det virtuelle rum virker således skræmmende, fordi der ikke er mulighed for at afkode, hvad tavsheden betyder. Omvendt kan man sige, at et indlæg viser, at man er til stede, hvorimod ens fysiske tilstedeværelse $\mathrm{i}$ et undervisningslokale ikke indeholder nogen garanti for mental tilstedeværelse og aktiv lytning.

\section{Virtuel understøttelse også i hverdagen på universitetet?}

Et spændende spørgsmål er, om vi også vil kunne have glæde af at integrere konference- og samarbejdssystemer i hverdagen på uddannelsesinstitutionerne? Det sidste år er det blevet forsøgt med introduktionen af Blackboard på DPU og SDU og SiteScape på Københavns Universitet Humaniora og Handelshøjskolen i København. Men det har vist sig, at den reelle brug af systemerne er forblevet yderst begrænset. Vi har at gøre med seje kulturelle barrierer. Brugerne skal kunne føle, at det for dem kan betale sig at give sig i kast med det ikke ringe arbejde, det er at lære systemerne at kende teknisk som pædagogisk-kommunikativt.

Dokumenter vil kunne lagres og arkiveres i systemet og kan findes og aktiveres af brugerne alle steder fra og til en hvilken som helst tid. I modsætning til papirversioner og disketter, som let kan blive væk eller bliver glemt og derfor ikke er tilgængelige, når man allermest har brug for dem, så vil man via et virtuelt samarbejdssystem altid - hvis man tager sig tid, og hvis man har tilegnet sig visse grundlæggende organisatoriske kompetencer - kunne genfinde dem og genanvende dem. Bygge videre på dem, således at der for alle brugere kan opstå en reel progression i ens arbejdsprocesser.

Studerende vil i den nye lærings- og samarbejdskultur kunne finde inspiration hos hinanden, give hinanden ideer til litteratur, skabe større fora for drøftelse af fx metodeovervejelser. Via systemet kan man dele links med hinanden og på den måde få kendskab til spændende og relevante websteder. Undervisningsmateriale, læreroplæg og online publikationer vil kunne tilbydes inden for disse rammer. 
Men som nævnt skal vi bryde med gældende kulturelle mønstre. Ejerfornemmelser i forhold til materiale, som "kun jeg skal kunne have nytte af", vil hæmme udbredt og fornuftig brug af systemerne. Generthed og tilbageholdenhed i forbindelse med ulysten til at lægge "ufærdige" indlæg og ideer ud til offentlig beskuelse må man også åbent refleksivt forholde sig til. Allerede i dagens fysisk lokaliserede uddannelsesinstitutioner kender vi til den enkeltes angst for ikke at kunne leve op til de andre gruppemedlemmers forventninger Vi kender til den store del af studerende, som på tilstedeværelsesseminarer er tilbageholdende og tavse. Inden for både den fysiske som den virtuelle kultur er det vigtigt at forsøge at etablere en atmosfære præget af tolerance, forståelse og nysgerrighed. Lykkes det, vil flere deltagere være mere trygge ved at fremkomme med deres synspunkter og også lægge skriftlige bidrag frem i virtuelle konferencer, selv om de netop er ufærdige og idéudkast. Den største udfordring i forhold til en videre brug af systemerne vil være at skabe forståelsen for fordelene ved etableringen af en fælles "social kultur" og tillige, som det kan ses gennem vores case, at eksperimentere med udarbejdelsen med forskellige klare "spilleregler", som gør det mere motiverende for studerende og lærere i bred forstand at blive aktive brugere.

\section{Konklusion}

I vores case med MIL-seminaret har vi set, hvordan man gennem en bevidst organisering af kurset undgik den tavshed, som ellers ofte "opstår" i virtuelle omgivelser. Vi oplevede en flerstemmig diskussion og dialog på højt fagligt niveau og så hvordan de omhandlede problemfelter blev analyseret og anskuet fra mange sider. Forudsætningen var en klar og bevidst didaktisk planlægning og tilrettelæggelse af formstruktur, deltagerroller og evalueringskriterier. Forløbet gav for deltagerne mulighed for fleksibilitet og tilbød samtidig rum for refleksion.

\section{Litteratur}

Agertoft, Annelise et al. (2003a). Netbaseret kollaborativ loering - en guide til undervisere. Værløse, Billesø \& Baltzer. Udk. nov. 2003

Agertoft, Annelise et al. (2003b). Deltager i netbaseret laering - en guide til samarbejde. Værløse, Billesø \& Baltzer. Udk. nov. 2003

Dysthe Olga. Det flerstemmige klasserum - skrivning og samtale for at loere. Århus, Forlaget Klim 1997.

Dysthe, Olga. "Læring gjennom dialog" - hva inneber det i høgare utdanning?". Dysthe, Olga (ed.). Ulike perspektiv på laering og laeringsforskning. Oslo, Cappelen Akademisk Forlag, 1999. 105-135.

Dysthe, Olga. "Dialogperspektiv på elektroniske diskussioner". Dysthe, Olga (ed.). Dialog, samspil og laering. Århus, Forlaget Klim, 2003. 311-334.

Sorensen, Elsebeth K. (2003a).'Designing for Collaborative Knowledge Building in Online Communities of Practice". Eight Contributions on Quality and Flexible Learning. Eds. Hansson H. \& C. Holmberg. Report 3: Hässleholm, Swedish Agency for Flexible Learning. 2003.

Sorensen, Elsebeth K. (2003b). "Designing for Online Dialogue and Discussion in Collaborative Knowledge Building Networks". SOFFs skriftserie 1/2003. SOFF - Centralorganet for fleksibel læring i høgre utdanning. Universitetet i Tromsø. 21-34. 